\title{
EFL Learners' Pedagogical Views on the Online Social Networks in EFL Classrooms
}

\author{
Heri Mudra \\ State Islamic Institute of Kerinci, Jambi, Indonesia \\ Amirul Mukminin \\ Universitas Jambi, Indonesia \\ Fridiyanto \\ UIN Sulthan Thaha Saifuddin Jambi, Indonesia \\ Marzul Hidayat \\ Universitas Jambi, Indonesia \\ Lenny Marzulina \\ Universitas Islam Negeri Raden Fatah Palembang, Indonesia \\ Kasinyo Harto \\ Universitas Islam Negeri Raden Fatah Palembang, Indonesia \\ Muhamad Holandyah \\ Universitas Islam Negeri Raden Fatah Palembang, Indonesia \\ Dian Erlina \\ Universitas Islam Negeri Raden Fatah Palembang, Indonesia
}

\begin{abstract}
This present study aims to explore EFL learners' pedagogical views towards the utilization of online social networks in EFL classrooms. It specifically elaborates the EFL learners' preferences of online social networks for learning English. Moreover, the EFL learners' English skills enhanced by utilizing online social networks were also investigated. Ten EFL learners participated in the qualitative study which employed observations and interviews in collecting qualitative data. The results show that the learners' preferences include Facebook, blogs, WhatsApp, Twitter, podcasts and Instagram. The learners' English skills improved include listening, writing, reading, and speaking. In conclusion, online social networks are not only designed for general communication among EFL learners, but also for engaging EFL learners to work collaboratively in learning English via online environments.
\end{abstract}

Index Terms-EFL classrooms, EFL learners, online social networks, pedagogical views

\section{INTRODUCTION}

Online social networks (OSN) such as Facebook, Wikipedia, WhatsApp, Blog, Twitter, Podcasts or Youtube have been widely used as easy, cheap, and fast communication tools for both written and oral communication in English (Chakowa, 2018; Habibi et al., 2019; Mukminin et al., 2019). Due to the advantages, OSN not only become the main topic of a talk (Silius et al, 2010), but also begins to be more popular among EFL learners who utilize OSN as simple, advanced tools for communicating in English lessons. In educational context, OSN have been accepted as well-known tools which are advantageous for English learning (Fewkes\& McCabe, 2012; Fischer, 2013; Mukminin et al., 2020). OSN which consist of many kinds of interesting platforms give several benefits for both EFL teachers and learners during teaching and learning process. The teachers and learners obtain various materials from different resources, discuss learning materials, and allow learners to work with the teacher and other learners in the EFL classroom (Mudra, 2018; Smith, 2006; Prasojo et al., 2018; Prasojo et al., 2019).

Advancement of online technology helps to encourage the development of online applications and websites such as OSN which promote EFL learners' autonomous learning in terms of multimodal literacies (Pegrum, 2009). Moreover, it is important for EFL teachers and learners to work with different kinds of OSN during the English lesson as it helps to improve English learning (Cifuentes \& Lents, 2011), encourages learners to increase motivation (Sweeny, 2010; Mukminin et al., 2020), and allows both learners and teachers to discuss what they are going to do in the EFL classroom 
(Cifuentes \& Lents, 2011). Such different kinds of OSN are designed for different functions and the EFL teachers are expected to select a tool that meets the learning objectives (Calvo, Arbiol \& Iglesias, 2014). Little research has been conducted in terms of pedagogical views of OSN in the EFL classroom. This current study was undertaken to shed light upon the importance of social networks in enhancing EFL learners' English skills. Therefore, it is a need to formulate several guided questions as the focus of the current study, as follows: 1) What kind of OSN do the EFL learners prefer in learning English? And 2) What learners' English skills are improved by employing OSN in the EFL classroom?

\section{LITERATURE REVIEW}

\section{A. Online Social Networks and English Language Teaching}

There is a widespread use of OSN in communicating information and messages. This trend has moved forward as the EFL teachers and learners increase their awareness to improve English skills via OSN. OSN are designed based on the need of easy and fast communication for peer users or community. OSN, which are also called social networking sites, are defined as "web-based sites that provide services which enable people to do three things: "(a) construct a public or semi-public profile within a bounded system, (b) articulate a list of other users with whom they share a connection, and (c) view and traverse their list of connections and those made by others within the system" (Boyd \& Ellison, 2007, p. 211). Interconnected systems designed in OSN ensure that EFL teachers and learners obtain more experiences to communicate in English and improve English skills simultaneously. They also create both public group which are open for many people and private group which are limited on particular teachers or learners.

Online learning environment allows teachers and learners to actively participate in learning community or group and build learning behaviors as they perform in offline learning environment (LeNoue, Hall, \& Eighmy, 2011). Likewise, the use of OSN for learning English skills is determined by five standards of OSN, namely communication, collaboration, community, creativity, and convergence (Friedman \& Friedman, 2008). Communicating knowledge is employed by collaborating with other teachers or learners. Collaborative English learning develops positive results of learning as it helps to accommodate learning styles (Chen, Jones, \& Xu, 2018). Particular group of community should be created via OSN and each member is allowed to take a part in it. Creativity is important in communicating information and messages among teachers and learners as group members. This is to achieve similar goals for improving learners' English skills. In short, social networks encourage EFL teachers and learners to work in group and share and discuss information online that reflect the goal in education (Robinson, 2008; Leach, 2013).

\section{B. Online Social Networks in EFL Classrooms}

In the EFL classroom, various types of OSN are paramount to be utilized as the tools for learning English. Each type of OSN is proposed to help EFL learners to join in online conversations or tasks, give their ideas or thoughts toward the messages or texts, watch videos, listen to audio files, and be engaged in online peer or group discussion (Chotipaktanasook, 2016). The following types of OSN are popular and appropriate for teaching and learning English online. OSN, which include online social networking sites (e.g Facebook), photo sharing (e.g Flickr, Instagram), recording audios and videos (e.g podcasts), blogs (e.gblogspot, wordpress), and microblogs (e.gWhats App, Twitter), are designed for enhancing EFL learners' English skills (Forlano, 2009; Blattner \& Fiori, 2009; Lomika \& Lord, 2009; Stevenson \& Liu, 2010; Mills, 2011; Brick, 2011; Meskill \& Quah, 2012; Grahl, 2013; Lamy \& Zourou, 2013).

\section{Social Networking Sites (SNSS)}

EFL learners are now offered with most widely used OSN. Social Networking Sites (SNSs) are mostly used in communicating messages or information. For EFL learners, Facebook has become the most popular network for learning English through online group discussion. Facebook as one of the SNSs application is another better option for EFL learners who expect a more organized system of communicating knowledge. It is because Facebook indulges EFL learners to work collaboratively and actively, and it is 'even more robust ways to create, connect, and collaborate around teaching and learning in the classroom' (Morin, 2007).

The reason why Facebook is widely used in EFL classrooms is because it has been well-known by many teachers and learners and it provides learners with fast online communication for learning and teaching (Castells, 2007; Calvi, Cassella, \& Nuijten, 2010). Likewise, Selwyn (2009) states that the use of Facebook as popular OSN for learners is because it offers simple platform system and it serves learners with safety and user-friendliness. In learning environment, Facebook improves EFL learners' skill in writing by allowing the learners to have ideas brainstorming and participate in positive discussion (Yunus \& Salehi, 2012). Another way of learning English through Facebook is that the EFL learners join online discussion forum via Facebook group and ask other learners to view task description and online discussion which provide fast track of communicating knowledge (Kosik, 2007). As for EFL teachers, Facebook application is used to share information about class assignment, homework, and course materials which can be easily accessed by the EFL learners online (Nicole, 2007).

\section{Microblogs}

One of the most important learning networks in term of microblogs is WhatsApp application. This OSN enables EFL teachers and learners to send a message or text related to EFL courses. They can also create a particular group which 
allows each member to interact with each other. In WhatsApp EFL learners are able to work with short messages which enable them to come up with precise ideas. Besides, the learners can also send, comment, and discuss every text, recorded files, and other attachments. It is important to note that WhatsApp also enables the learners to have an online discussion forum via this online environment. This is, of course, a particular objective of online learning (Dehghan, Rezvani, \&Fazeli, 2017).

WhatsApp as a type of OSN has become a widely used online application in the EFL classroom. The reason is because WhatsApp allows EFL teachers or learners to send or receive short texts easily. It does not take a long time for EFL learners to communicate messages or information via such online application as long as signal remains stabilized. Each learner can also enhance both English skills and social learning behaviors (Church \& de Oliveira, 2013). In this case, the learners not only learn how to be fluent English learners, but also how to use polite, appropriate, and qualified utterances or messages. Moreover, EFL learners who utilize WhatsApp as online learning application are able to develop their motivation to learn English collaboratively and to enhance online learning behaviors as they manifest the application as a daily communication tool (Bere, 2013; Rambe \& Chipunza, 2013).

\section{METHOD}

\section{A. Participants}

The participants of this current study were ten EFL learners in a public school in Indonesia. They were attending English courses in semester two. The reason for selecting the participants is because they were fresh EFL learners who began learning English in an undergraduate program and working with other learners collaboratively. Purposive sampling technique allowed the selection to be more accurate and considerable. They were also selected based on previous observation and pre-research which showed that they were legible to participate in the qualitative study. More importantly, the participants were actively engaged in online networks and by this reason they were considered to have more experiences in utilizing social networks as online tools for communication.

\section{B. Data Collection and Instruments}

To collect qualitative data, both participants and non-participants observations and semi-structured interviews were administered intensively. Both techniques in collecting the data were undertaken respectively. First, participant observation enabled the researchers to join an English club group created by EFL teachers and learners. In this case, passive interaction with the learners and paying attention towards the learners' online discussion were focused. Another technique was by analyzing how the learners work with each other toward assignment, explanation, information, or other messages sent by either teachers or other learners. This technique was done by asking for permission from the learners to read and analyze their created group. The group consisted of Facebook and WhatsApp group community learning.

Another important technique for collecting the qualitative data was by interviewing each learner regarding their experiences in utilizing OSN, preferences for using particular types of OSN, and impact of OSN on their English skills. These semi-structured interviews were employed after observing the learners' online activities. One-by-one learners as participants were interviewed and asked to describe what they truly knew about learning via online environments and why they tended to keep doing such online learning.

\section{Data Analysis}

To analyze the data, several steps were accomplished. First, the data obtained from the observations and interviews were coded and this helped to accurately select the data among the raw data. Second, the data were categorized in terms of focused and saturated data. Third, the data were configured by undertaking data triangulation. The data were checked based on its field certainty, completeness, and qualitative quality. Fourth, the data were interpreted by connecting each finding with related, suitable references. In short, the data were coded, reduced, displayed, verified, and reflected (Miles, Huberman, \& Saldana, 2002; Mukminin, \& McMahon, 2013; Mukminin, 2019).

\section{FINDINGS}

In this subpart, the results of the present study were categorized based on emerging topics from the interviews. The results show that there were preferences of OSN. Moreover, the results also present learners' experiences in enhancing their English skills during the utilization of preferred OSN.

\section{A. EFL Learners' Preferences towards Online Social Networks}

The following results of interviews show EFL learners' preferences include Facebook, WhatsApp, blogs, podcasts, Twitter, Instagram.

\section{Facebook}

Facebook is one of the preferences of OSN as viewed by EFL learners in learning English. L1, for example, utilized Facebook to write in English. His main goal was to join giving English comment to his teacher's wall. L1 states: 
I like Facebook. It helps me a lot. My English teacher writes a status update. I comment on her wall. Wow, really good for me English. (L1)

Different from previous learner, L6 preferred Facebook to interact with many people from various countries such as from native countries.

Of course, I prefer Facebook and always Facebook. Why? Because it gives learning experiences for me. I can

learn many things from many people. I have some friends from other countries as well. (L6)

As stated by L6, interacting with other people whose language is the target language of the EFL learners helps to extend learning experiences. Facebook as one of the types of OSN allows the EFL learners to chat with native English speakers.

\section{WhatsApp}

The strength of WhatsApp has gone through its ease and access. L2 believes that learning English via WhatsApp is interesting. L2 comments:

WhatsApp is open everytime in my smartphone. It is easy for everyone to use it. We can chat in English, talk about tasks and homework from lecturers easily. It is not expensive and it is fast. (L2)

L2 mentions the benefits of WhatsApp for EFL learners. Each EFL learner who was registered can discuss in English collaboratively. Its effectiveness helps learners to share English lessons via online environment.

If I am asked to choose, yes, I choose WhatsApp application to learn English. I and my friends usually make a group and learn English there. We share many materials of English in there. What I know is WhatsApp goes faster than another application. (L10)

L10 is no exception. She created a group which allows every member to use English when they are in. L10 believed that learning English via WhatsApp enables each learner to upload and download materials for their English learning.

\section{Blogs}

Blog as a type of OSN is useful for keeping files safely and keeping written thoughts. L4 has more experiences in a blog. Better EFL learners indulge themselves to English world. English is regarded as proper tool for learning.

The answer is my blog and long time ago I made my blog. My blog is fun. I put everything about English in my blog. I even write and post everything about English. What I want there. (L4)

However, L5 has another focus when working with blogs. For him, blog helps EFL learners to utilize free, proper tool for learning. Self writing in a blog is important for EFL learners.

Blog, blogging, blogger. I am a blogger. Using blog is cheap, free, no payment. I express myself. I share my mind in my blog wall. It lasts for longer time. (L5)

\section{Podcasts}

Several EFL learners are aware of authentic materials for their English learning. L7, for example, preferred listening to natural speeches by native speakers such as president speech. American accent directed the EFL learner to listen to American voice only. This does not look harmful.

Hmmm..... I prefer recording files from the internet. I like listening to Obama's speech. I think his speech is clear voice. I do not like listening to western songs. I think the song is not worthy for me. I like listening to American sound recording. Their voices are really good to hear. (L7)

\section{Twitter}

One of the participants, L3, preferred to use Twitter as online learning tool for learning English. Learning is successful when simple-designed online tool is utilized by other members of Twitter application. L3 states:

I never stop loving Twitter. Twitter, we know, Twitter is simple and design is simple. I just find it easy and simple to discuss English topics via twitter. (L3)

\section{Instagram}

It is not easy to redefine the use of Instagram in EFL classroom. Fortunately, Instagram as one of OSN tools can be used by posting a picture. Some learners, then, are asked to give some comments towards the achievement. L8 admits:

Do not you think Instagram is interesting with colorful design? I think so. We can post our English picture to

be discussed with our friends. We can see English pictures from many countries. Just use it for learning. (L8)

The EFL teacher can also post some pictures and ask EFL learners to write a comment or retell a story based on the picture.

Many English drawing pictures in Instagram. So, it is not a problem to use Instagram to learn English. I myself know my language, but I comment to the picture in Instagram. I use my English. Sometimes, people from other countries talk to me after comment their pictures. (L9)

\section{B. Enhanced Learners' English Skills}

The following results of interviews show English learners' skills improved via online social networks. It includes listening, writing, reading, and speaking. 


\section{Listening}

Listening as one of complicated skills faced by EFL learners is important to be enhanced via online learning environments. L5 improved listening skills by watching videos via Youtube. The videos let the EFL learners to figure out some paralinguistic features. One of the strategies to get knowledgeable with listening is by synthesizing language and context in the video.

My English listening is improving. I success to improve it. How to do it is by watching many videos like videos from Youtube. Many videos are good for listening. In Youtube, I watch expressions and actions and I listen to its language. I can listen better because I combine watching and listening. (L5)

There are many features that can be learnt via podcasts. L7 argued that podcasts were valuable to be a good listener in English. It is because podcasts contain authentic language which is used by native English speakers in their everyday life. These authentic materials are paramount for EFL learners who are supposed to be active listeners like L7.

Again, podcasts are my popular files to learn English. I love listening to music, speech, story. When I listen to recording of podcasts, I learn much. I learn many things. We know that language used in podcasts is natural and native. It makes me confident to listen to podcasts. (L7)

\section{Writing}

Learning English via social networks such as WhatsApp has positive impacts on EFL learners' writing skill. L2 believed that writing was challenging when it is integrated with OSN such as WhatsApp. Writing a text to be read by other learners is also challenging. The learner has to write correct grammar and proper dictions if the texts are expected to be understood. L2 faced an ambiguous situation. Shortening a word might be simple, but reduce quality of correct grammatical sentences.

First, I never like writing. Fortunately, WhatsApp brings me to a new world of writing. Writing a message, writing information, writing materials in WhatsApp are challenging for me. Many models of writing are found in writing in WhatsApp. I shorten some words like "and" becomes "n", "because" becomes "bcs". I do not know it is wrong or correct. I just try the best for grammar. I type many sentences faster in WhatsApp. (L2)

Unlike previous learner, L3 who preferred to write in Twitter has pedagogical experiences in learning English via online application. Twitter was used by EFL teacher in writing a sentence. The sentence or statement should be responded with a comment which was also in English. Such strategy motivates learners to think about grammatical sentence and proper vocabulary before posting a comment to teacher's statement.

I get experiences to write something in Twitter or to give comment to my teacher and classmates. Twitter wants me as EFL learners to write better. I always try to write in English in Twitter. But, I look up dictionary online before I post my writing. Some classmates and teachers and other people comment for me. I always try to use good grammar, because I believe it is not easy for others to understand my writing with bad grammar. Then, I always respond in good English with good grammar because I want to train my English. (L3)

The use of Facebook as an online network in learning English has enhanced EFL learners' writing skill. The learners are motivated to share knowledge via Facebook. This allows them to write faster, but the writing follows the rules.

I have used Facebook for long time. I am not shy to write in English. My classmates and I make a group in Facebook. We share materials for English lessons from our teacher. We talk about homework. Those who work with difficult question can teach us. Really simple, but give more motivation for me. I give comments to classmates who post something. The point is writing in Facebook is simple to do. Nobody forces us as learners to learn English. (L6)

L9 tended to write by referring abstract ideas to physical pictures. Writing an abstract idea can be difficult for some EFL learners. Fortunately, Instagram helps the learners to work with both picture and its caption.

I like writing in Instagram wall. In the wall, there is always pictures that use English language. My teacher asks us to work in pair and we are asked to give comment to a picture. Besides, we are also asked to post a picture, and other groups must write a comment for our picture. This activity is fun and enjoyable. That is why writing is not too difficult for me to do. (L9)

\section{Reading}

L1 liked reading various texts via OSN such as Facebook. The texts were mostly authentic and the learner was motivated to learn real usage of English as used by native English speakers.

Facebook provides features to upload reading files. I tend to upload many reading texts in my Facebook wall. I want to help other EFL learners who need the materials. I also read the materials when I have much time. I also like to read reading texts in Facebook. I can easily find links to online newspapers, advertisements, announcements, and many more I can find in my Facebook wall. Well, I like reading online news. It has good grammar to learn. I can learn grammar from every reading text I surfed. It is update via my Facebook wall. (L1)

WhatsApp is useful in sharing reading files such as novels and short stories. L10 obtained advantages from WhatsApp application in increasing reading skill.

My hobby is reading English novels and shorts stories also in English. I have many classmates and other friends from other campuses who have same hobby. We always talk about English novels and short stories in 
our online WhatsApp group. I enjoy talking about that. We share novels and short stories each other. We read the novels or short stories. We discuss the reading files. (L10)

\section{Speaking}

L4 believed that blog gave a positive experience for enhancing oral skills. This social network is also beneficial for keeping video and audio files for speaking skill.

About my speaking, I am honest that my spoken ability is developing from days to days. I watch videos and listen to audios I uploaded in my blogs. One day, I have a task from my teacher to retell a story. Because I always practice it in my blog, I did it pretty well. I ensure that I apply grammatical rules in my utterances. My blogs also provide many links to conversation examples made by educators from native countries. I learn speaking from the link and its websites. (L4)

Speaking skill can be enhanced via Instagram. Shortened English videos in Instagram allow learners to give some comments which can increase their oral skill.

I and my classmates have some groups in Instagram. We have many shortened videos there in the groups. Once a week, we learn how to speak well via the group. The videos are interesting. We watched the videos. We give our opinions. Our teacher even motivates to watch short videos in Instagram and retell the video story in front of the class (L8)

\section{DISCUSSION}

This present study focuses on two objectives, namely EFL learners' preferences towards OSN and English skills enhanced via OSN. As for the findings, it is noted that EFL learners prefer various online application for learning English. They include Facebook, WhatsApp, Twitter, Instagram, blog, and podcasts. Each type of OSN gives positive impacts on EFL learners' English skills. These online networks are proper tools for developing skills in listening, writing, reading, and speaking. Facebook as the most widely used online application is an appropriate tool for EFL learners to enhance their writing skill. The EFL learners become motivated to write in English as they are free to share their ideas. This is in line with a study by White (2009) who found that Facebook improves EFL learners' writing skill and increases their motivation to write in English. Moreover, Facebook enables EFL learners to be indulged in learning English and to be able to adapt themselves in learning situation (Roblyer, 2010). This study also reveals that Facebook helps EFL learners to keep writing a sentence with correct grammatical rules. The EFL learners are aware of each grammatical element such as parts of speech, formula, diction, and sentence structure. In the same vein, Blattner and Lomicka (2012) state that discussion forum in Facebook gives EFL learners some clear description on how to write with high-quality grammatical rules. Moreover, learners can develop their socio-pragmatic competence which is useful for their writing styles. In short, Facebook is valuable for developing pedagogical process and motivation of learning English in the EFL classroom by sharing ideas and describing what has already been known (Ulf, 2010; Kabilan, Ahmad, \& Abidin, 2010).

A type of OSN which enhances learners' reading skill is WhatsApp. The EFL learners become motivated to read a text via WhatsApp since the online application is fast, cheap, but smart. In line with that, the finding of Plana et al (2013) proved that WhatsApp as OSN gives much motivation for learners to read various texts in English. The use of Facebook is advantageous for enhancing learners' reading skills. To get successful in reading, the EFL learners are expected to be active to work with peers or groups and share information via online application. This is supported by a study of Blattner and Fiori (2009) who believed that Facebook increases EFL learners reading skill through collaborative work, peer discussion, knowledge integration, and group discussion forum. Moreover, online discussion forum enhances EFL learners' collaborative work which results in mutual understanding towards English skills (Chadha, 2017).

This current study also shows that learners' oral skills can be enhanced via blog as a communicative tool for learning how to speak. The EFL learners are motivated to create a blog, save videos and audios, and interconnect several links to other websites that enable them to increase their oral skills. Such finding is in harmony with a study by George and Dellasega (2011) who proved that blogging is communicative in nature. It serves as one of the online networks for teaching and learning oral English skills. The EFL learners act as active users who develop oral skills through sharing information or describing past experiences with classmates. However, a result of Campbell's (2007) study warned that online discussion community might divide EFL learners into those who have better spoken ability and those whose oral skills are lower. Above all, social networks have better impacts on pedagogical process in learning English skills including writing, grammar, vocabulary, reading, listening, and oral skills. Learners' motivation to write, listen, talk, and read is developed as they are engaged in online learning environment. The social networks can also develop English competence and enable EFL learner to be engaged in practical application for learning English (Dieu, 2004; Lee, 2010; $\mathrm{Wu} \& \mathrm{Wu}, 2011$ ). As for accessibility, the use of smartphones has shed light upon the importance of OSN in improving EFL learners' English skills (Alkhezzi, 2016; Mudra, 2018).

\section{CONCLUSION}


To sum up, social networks which are administered as online applications are designed not only for the purpose of daily communication, but also serve as a pedagogical tool in the EFL classrooms. As proper online tools for learning English, each type of social networks contains advantages and disadvantages. The EFL learners are expected to select OSN they consider to be appropriate for their English learning enhancement. This means that no social networks have more strength and, otherwise, no social networks have more weaknesses. The social networks act as tools for learning English. The online networks do not work by themselves or do not create contents automatically. EFL teachers are expected to guide EFL learners before utilizing any kind of OSN. In this case, the teachers' strategies are highly needed to promote interactive and communicative classrooms. Such strategies enhance the learners' motivation to learn English and they become autonomous learners (Jacobi, 2018). Positive learning situation is always contributed by active collaboration between teachers and learners. On the other hand, advanced technology is managed, planned, developed, and reflected by the teachers who consider learners' English skill improvement.

\section{REFERENCES}

[1] Alkhezzi, F. (2016). The Impact of Mobile Learning on ESP Learners' Performance. The Journal of Educators Online, 13(2), 73-101. Available from https://files.eric.ed.gov/fulltext/EJ1106736.pdf (accessed on July 10th, 2021)

[2] Bere, A. (2013). Using mobile instant messaging to leverage learner participation and transform pedagogy at a South African University of Technology. British Journal of Educational Technology, 44(4), 544-561. https://doi.org/10.1111/bjet.12057

[3] Blattner, G., \& Fiori, M. (2009). Facebook in the language classroom: Promises and possibilities. International Journal of Instructional Technology and Distance Learning, 6(1), 17-28.

[4] Blattner, G., \& Lomicka, L. (2012). 'Facebook-ing and the social generation: A new era of language learning', Alsic (Apprentissage des languesetsystèmesd'informationetde communication). Available from http://alsic.revues.org/2413 (accessed on July 12th, 2021)

[5] Boyd, D. M., \& Ellison, N. B. (2007). Social network sites: Definition, history, and scholarship. Journal of Computer-Networksted Communication, 13(1), 210-230. https://doi.org/10.1111/j.1083-6101.2007.00393.x

[6] Brick, B. (2011). Social Networking Sites and Language Learning. International Journal of Virtual and Personal Learning Environments (IJVPLE), 2(3), 18-31. https://doi.org/10.4018/jvple.2011070102

[7] Calvi, L., Cassella, M., \& Nuijten, K. (2010). Enhancing users' experience: A contentanalysis of 12 university libraries Facebook profiles. ELPUB 2010 International Conference on Electronic Publishing, Helsinki.

[8] Calvo, R., Arbiol, A., \& Iglesias, A. (2014). Are all chats suitable for learning purposes? A study of the required characteristics. Procedia Computer Science, 27, 251-260. https://doi.org/10.1016/j.procs.2014.02.028

[9] Campbell, N. (2007). Bringing ESL students out of their shells: Enhancing participation in public discourse through online writing in ESL instruction. Business Communication Quarterly, 70, 37-43. https://doi.org/10.1177/108056990707000105

[10] Castells, M., et al. (2007). Mobile communication and society: A global perspective. Cambridge, MA: The MIT Press.

[11] Chadha, A. (2017). Comparing Student Reflectiveness in Online Discussion Forums across Modes of Instruction and Levels of Courses. Journal of Educators Online, 14(2), 1-19 https://doi.org/10.9743/jeo.2017.14.2.8

[12] Chakowa, J. (2018). Enhancing Beginners' Second Language Learning Through an Informal Online Environment. Journal of Educators Online, 15(1), 1-14. https://doi.org/10.9743/JEO2018.15.1.7

[13] Chen, C., Jones, K., \& Xu, S. (2018). The Association Between Students' Style of Learning Preferences, Social Presence, Collaborative Learning and Learning Outcomes. Journal of Educators Online, 15(1), 1-16. https://doi.org/10.9743/JEO2018.15.1.3

[14] Chotipaktanasook, N. (2016). Using social networks in the EFL classroom for the enhancement of low affective filter and willingness to communicate. Proceeding of The Seventh CLS International Conference CLaSIC (pp. 56-64). Singapore: National University of Singapore (NUS) Press.

[15] Church, K., \& de Oliveira, R. (2013). What's up with WhatsApp? Comparing mobile instant messaging behaviors with traditional SMS. Proceedings of the 15th International Conference on Human-computer Interaction with Mobile Devices and Services (pp. 352-361). ACM.

[16] Cifuentes, O. E., \& Lents, N. H. (2010). Increasing Student-Teacher Interactions at an Urban Commuter Campus through Instant Messaging and Online Office Hours. Electronic Journal of Science Education, 14(1), 1-13. Available from http://wcsu.idm.oclc.org/login?url=http://search.ebscohost.com/login.aspx?direct=true \&db=ehh\&AN=72320006\&site=ehost-li ve\&scope $=$ site $\left(\right.$ accessed on June $\left.29^{\text {th }}, 2021\right)$

[17] Dehghan, F., Rezvani, R \& Fazeli, S. A. (2017). Social networks and their effectiveness in learning foreign language vocabulary: A comparative study using Whatsapp. CALL-EJ, 18, 1-13. Available from http://callej.org/journal/18-2/Dehghan-Rezvani-Fazeli2017.pdf (accessed on June 24th, 2021)

[18] Dieu, B. (2004). Blogs for language learning. Essential Teacher, 1(4), 26-30. Available from http://beespace.net/blog/wp-content/uploads/2007/05/autumn-2004-portal.pdf (accessed on March 30th, 2021)

[19] Fewkes, A. M., \& McCabe, M. (2012). Facebook: Learning tool or distraction? Journal of Digital Learning in Teacher Education, 28(3), 92-98. https://doi.org/10.1080/21532974.2012.10784686

[20] Fischer, Y. (2013). The Facebook is dead- long live WhatsApp. De Marker. Available from http://www.themarker.com/technation/1.2126492. (accessed on July 1st, 2021)

[21] Forlano, D. (2009). Social networking for language learning. The Language Educator, 4(1), $43-45$.

[22] Friedman, L.W. \& Friedman, H. H. (2008). High impact areas of the new networks technologies: A review. Management Online Review, July. Available from http://www.morexpertise.com/download.php?id=97 (accessed on July $23^{\text {rd }}, 2021$ )

[23] George, D. R., \& Dellasega, C. (2011). Use of social networks in graduate-level medical humanities education: two pilot studies from Penn State College of Medicine. Medical teacher, 33(8), e429-e434. https://doi.org/10.3109/0142159X.2011.586749 
[24] Grahl, B. (2013). 'The networks of social networks'. Available from http://tristantreadwell.wordpress.com/tag/grahl/ (accessed on July $23^{\text {rd }}, 2021$ )

[25] Habibi, A., Razak, R. A., Yusop, F. D., \& Mukminin, A. (2019). Preparing future EFL teachers for effective technology integration: What do teacher educators say? Asian EFL Journal, 21(2), 9-30.

[26] Jacobi, L. (2018). What Motivates Students in the Online Communication Classroom? An Exploration of Self-Determination Theory. The Journal of Educators Online, 15(2), 1-16. https://doi.org/10.9743/jeo.2018.15.2.1

[27] Kabilan, M. K., Ahmad, N., \& Abidin, M. J. Z. (2010). Facebook: An online environment for learning of English in institutions of higher education? Internet and Higher Education, 13, 179-187. https://doi.org/10.1016/j.iheduc.2010.07.003

[28] Kosik, A. (2007). The implications of Facebook. Sharing the Commonwealth: Critical issues in higher education. Available from http://www.pcpa.net/March2006.pdf. (accessed on June 5th, 2021)

[29] Lamy, M.-N., \& Zourou, K. (Eds.). (2013). Social networking for language education. Basingstoke: Palgrave Macmillan.

[30] Leach, J. (2013). What Is Social Learning (And Does It Work)? Available from http://www.knowledgetransmission.com/what-is-sociallearning-infographic/ (accessed on June $\left.1^{\text {st }}, 2021\right)$

[31] Lee, L. (2010). Fostering reflective writing and interactive exchange through blogging in an advanced language course. ReCALL, 22(2), 212-222.

[32] LeNoue, M., Hall, T., \& Eighmy, M. (2011).Adult education and the social networks revolution. Adult Learning, $22,4-12$.

[33] Lomika, L., \& Lord, G. (Eds.). (2009). The next generation: social networking and online collaboration in foreign language learning. San Marcos, TX: Computer Assisted Language Instruction Consortium (CALICO).

[34] Meskill, C., \&Quah, J. (2012). Researching language learning in the age of social networks. InH. Reinders\& M. Thomas (Eds.), Contemporary computer-assistedlanguagelearning (pp. 39-71). London: Bloomsbury Publishing.

[35] Miles, M. B., Huberman, A. M., \& Saldana, J. (2002). Qualitative data analysis: A methods source book. Los Angeles: Sage.

[36] Mills, N. (2011). Situated learning through social networking communities: The development of joint enterprise, mutual engagement, and a share repertoire. CALICO Journal, 28(2), 345-368.

[37] Morin, D. (2007). Education application opportunity. Available from http://developers.facebook.com/news.php?blog=1\&story=24 (accessed on June $3^{\text {rd }}, 2021$ )

[38] Mudra, H. (2018). Pre-Service EFL Teachers' Experiences in Teaching Practicum in Rural Schools in Indonesia. The Qualitative Report, 23(2), 319-344. Available from http://nsuworks.nova.edu/tqr/vol23/iss2/3 (accessed on July 11th, 2021)

[39] Mudra, H. (2018). A Study on the Attributes of Effective English Lecturers as Perceived by EFL Learners: The Case of Indonesia. Journal of Language and Education, 4(2), 73-81. https://doi:10.17323/2411-7390-2018-4-1-73-81

[40] Mukminin, A., Habibi, A., Muhaimin, Asrial, Haryanto, E., Setiono, P., \& Sofyan. (2019). Vocational technical high school teachers' beliefs towards ICT for the 21 st century education: Indonesian context. Problems of Education in the 21st Century, 77(1), 22-38.

[41] Mukminin, A., Habibi, A., Fridiyanto. (2020). Technology in the classroom: EFL teachers' technological pedagogical and content knowledge Tehnologija U Razredu: Tehnološka Pedagoška I Sadržajna Znanja Učitelja Efl-A. Informatologia, 53(1-2), pp. 24-36.

[42] Mukminin, A. \& Habibi, A. \& Muhaimin \& Prasojo, L. D. (2020). Exploring the drivers predicting behavioral intention to use m-learning management system: Partial Least Square Structural Equation Model. IEEE Access, 10.1109/ACCESS.2020.3028474

[43] Mukminin, A. (2019). Acculturative experiences among Indonesian graduate students in Dutch higher education. Journal of International Students, 9(2), 488-510.

[44] Mukminin, A., \& McMahon, B. J. (2013). International graduate students' cross-cultural academic engagement: Stories of Indonesian doctoral students on an American campus. Qualitative Report, 18(35). 1-19.

[45] Nicole, K. (2007). Lookabee's Facebook apps for teachers. Available from http://mashable.com/2007/10/01/lookabee/ (accessed on July 11th, 2021)

[46] Pegrum, M. (2009).Communicative networking and linguistic mashups on Web 2.0.In M. Thomas (Ed.), Handbook of Research on Web 2.0 and Second Language Learning (Vol. 2, pp. 20-41). Hershey, New York: Information Science Reference.

[47] Plana, M. G. C., Escofet, M. I. G., Figueras, I. T., Gimeno, A., Appel, C., \& Hopkins, J. (2013). Improving learners' reading skills through instant short messages: A sample study using WhatsApp. 4th World-CALL Conference, Glasgow, 10-13 July 2013.

[48] Prasojo, L. D., Mukminin, A., Habibi, A., Marzulina, L., Sirozi, M., \& Harto, K. (2018). Learning to teach in a digital age: ICT integration and EFL student teachers' teaching practices. Teaching English with Technology, 18(3), 18-32.

[49] Prasojo, L. D., Mukminin, A., Habibi, A., Hendra, R., \& Iqroni, D. (2019). Building quality education through integrating ICT in schools: Teachers' attitudes, perception, and barriers. Quality - Access to Success, 20(172), 45-50.

[50] Rambe, P., \& Chipunza, P.R.C. (2013).Using mobile devices to leverage student access to collaboratively-generated resources: A case of WhatsApp instant messaging at a South African University. International Conference on Advanced Information and Communication Technology for Education (ICAICTE 2013).

[51] Robinson, K. (2008). RSA animate: Changing education paradigms. Retrieved from http://www.youtube.comlwatch?v=zDZFcDGpL4U. $\quad$ Complete lecture $\quad$ available from http://wn.comlSirKenRobinsonChangingParadigms. (accessed on July 15th, 2021)

[52] Roblyer, M. D., McDaniel, M., Webb, M., Herman, J., \& Witty, J. V. (2010). Findings on Facebook in higher education: A comparison of college faculty and student uses and perceptions of social networking sites. The Internet and Higher Education, 13(3), 134-140. https://doi.org/10.1016/j.iheduc.2010.03.002

[53] Selwyn, N. (2009). Faceworking: Exploring students' education-related use of Facebook. Learning Networks and Technology, 34, 157-174. https://doi.org/10.1080/17439880902923622

[54] Silius, K., Miilumäki, T., Huhtamäki, J., Tebest, T., Meriläinen, J., \& Pohjolaine, S. (2010). Students' motivations for social networks enhanced studying and learning. Knowledge Management \& ELearning: An International Journal, 2(1), 70-80.

[55] Smith, S. S. (2006). Web-based instruction: A guide for libraries. American Library Association. 
[56] Stevenson, M. P., \& Liu, M. (2010). Learning a language with Web 2.0: Exploring the use of social networking features of foreign language learning websites. CAELL Journal, 27(2), 233-259.

[57] Sweeny, S. M. (2010). Writing for the instant messaging and text messaging generation: Using new literacies to support writing instruction. Journal of Adolescent \& Adult Literacy, 54(2), 121-130. https://doi.org/10.1598/JAAL.54.2.4

[58] Ulf, S. (2010). Motivation to write online: Chats and forums. GFL Journal, 1, 3-18.

[59] White, J. (2009). The use of Facebook to improve motivation and academic writing. Ritsumeikan University, Japan

[60] Wu, H.-J., \& Wu, P.-L. (2011). Learners' perceptions on the use of blogs for EFL learning. US-China Education Review, A3, 323-330.

[61] Yunus, M. M., \&Salehi, H. (2012). The effectiveness of Facebook groups on teaching and improving writing: Students' perceptions. International Journal of Education and Information Technologies, 1(6), 87-96. Available from https://research.iaun.ac.ir/pd/hadisalehi/pdfs/PaperM_7787.pdf (accessed on June 24th, 2021)

Heri Mudra was born in Kerinci, Indonesia, on December $16^{\text {th }}$, 1985 . Mudra is now a doctoral student in Education Science Program at Universitas Jambi, Indonesia. Mudra holds a magister degree in English Language Teaching and Mudra graduated from Universitas Negeri Padang, Indonesia in 2010. He is a senior lecturer at English Department of Institut Agama Islam Negeri Kerinci, Indonesia. He has published in several reputable international journals such as in The Qualitative Report Journal, Teaching English with Technology Journal, Journal of Language and Education. His research interests include TESOL, Educational Psychology, and ICT in education. Mr. Mudra is a reviewer of several national and international journals such as Research In Learning Technology Journal, Language Learning and Technology Journal, Journal of English in a Foreign Language, Journal of English Education and Linguistic Studies. He also serves as a member of editorial board in several national and international journals such as Indonesian Research Journal in Education, Edumatika Journal, and Tarbawi Journal.

Amirul Mukminin is a full professor, Universitas Jambi, Faculty of Teacher Training and Education, Indonesia. His research interests include education, language education, international education, educational policy and language policy.

Fridiyanto is an assistant professor, UIN Sulthan Thaha Saifuddin Jambi, Indonesia. His research interests include education, language education, multicultural education, educational policy and management.

Marzul Hidayat is an assistant professor, Universitas Jambi, Faculty of Teacher Training and Education, Indonesia. His research interests include education, applied linguistics, language teaching, TESOL, TEFL, language education, international education, educational policy and language policy.

Lenny Marzulina is an associate professor, Universitas Islam Negeri Raden Fatah Palembang, Indonesia. Her research focuses on language teaching, TEFL, and English education and applied linguistics.

Kasinyo Harto is a full professor, Universitas Islam Negeri Raden Fatah, Palembang, Indonesia. His research interests are teaching and learning in higher education, multicultural education, educational management, and education in Muslim countries.

Muhamad Holandyah Fridiyanto is an assistant professor, Universitas Islam Negeri Raden Fatah Palembang, Indonesia. His research focuses on language teaching, TEFL, and English education and applied linguistics

Dian Erlina is an associate professor, Universitas Islam Negeri Raden Fatah Palembang, Indonesia. Her research focuses on language teaching, TEFL, and English education and applied linguistics. 